\section{Alice Dautry}

The first woman to head Paris's prestigious Institut Pasteur, Alice Dautry inherited an ugly mess. One year into the job, she has already succeeded in getting the center back on track.

When Alice Dautry took the reigns of the Institut Pasteur in October 2005, the prestigious center was facing the worst crisis in its 118-year history. Two months earlier, her predecessor Philippe Kourilsky had been evicted after bitter disputes between staff and management, and after the institute's board had resigned en masse in protest.

Strolling across campus with Dautry in October, it is clear that the atmosphere has changed.

With smiles and bonjours and comment ça vas back and forth, the petite chief melts into the crowds as if she were just another researcher. Over lunch, she chats openly. "Don't you dare publish that in Nature," she says, laughing in response to a remark that the red wine is Domaine de l'Institut Pasteur - made at a vineyard donated to the institute.

It's perhaps this informal and approachable air that has helped Dautry calm the troubled campus. "You can't have orders coming down from on high; everyone has to participate," she says.

Dautry has a PhD from Paris-Sud University in solid-state physics but turned to biology after completing a master's degree in molecular biology at Stony Brook University. She came to the Pasteur in 1977 but maintains close links with the US through regular visits.

Since 1992, she had been head of Pasteur's Biology of Cell Interactions laboratory, studying immune system receptors and infections with intracellular bacteria. But her new job doesn't leave much time for her own research, she says.

For much of her first year, Dautry has been busy dealing with the problems that were at the heart of the dispute. In an attempt to expand and modernize the famed institute, Kourilsky had tried to force some labs at the institute, located in the left bank of Paris, to move to a bleak commercial zone in Fresnes on the city outskirts. Appalled researchers argued that the move would make it difficult to recruit bright young scientists, and become a recipe for intellectual death by isolation.

"Pasteuriens talk about Pasteur like a home, like a family," says Robert Ménard, a Howard Hughes fellow and head of the institute's Malaria Biology and Genetics lab. "So it was really like splitting a family."

Dautry is instead shuffling labs around the campus and renovating buildings one at a time. She is also planning to construct a 21,000-squaremeter building dedicated to infectious diseases - particularly virologywhich is seen as key to modernizing the campus.

"She's very down to earth, and very pragmatic," says Simon WainHobson, an AIDS virologist at the institute. "We don't hear lots of fancy phrases or bullshit and the situation is far less conflictual."

Dautry is enjoying a honeymoon longer than most new research administrators get to because people know she has a lot on her plate, says Wain-Hobson. "There is a lot to fix, and, to be fair, [it] is therefore too early to start throwing stones."
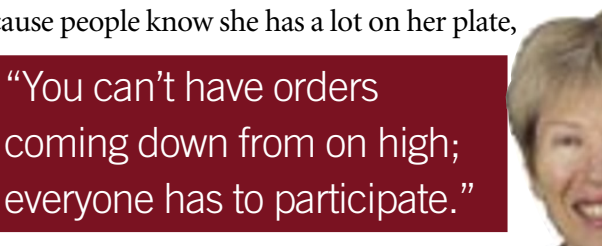

For the moment at

least, people are only throwing accolades her way.

The revolt last year was rooted in deep resentment about Kourilsky's brash management style and a widespread perception that technocratic reforms, and not science, were driving changes at the institute. Kourilsky tried to create "a
US style," at the French institute, adds Ménard, "a culture of competition within Pasteur for space and funding" that ended up scaring staff.

In contrast, Dautry is consulting with scientists, including on whether the institute should expand to a second campus or move entirely to a new site, but one with a better scientific environment than Fresnes. She began campus-wide discussions on the direction Pasteur should take, looking ahead to 2020. A scientific strategic plan thrashed out over the next year will drive the necessary reforms.

Dautry's appointment of Bernard Dujon as her scientific director has also sent a reassuring signal to staff. Dujon, a yeast geneticist, had been prominent in arguing that reforms needed to be driven by a scientific agenda, and not the other way round.

"I think she's exactly what we needed. She tries to take everybody's advice," says Pascale Cossart, a Howard Hughes fellow who heads the Bacteria-Cell Interactions lab at Pasteur. Kourilsky had been a "very dynamic director," Cossart adds, but didn't consult enough. "In the end, we decided we had to kick him out."

Dautry is keeping many of the measures intended to boost competition, including some of the reforms Kourilsky launched. She has also kept Kourilsky's priority of promoting young scientists through the creation of five-year programs, forcing a greater turnover of labs. "I completely backed the idea, it was a very intelligent one," says Dautry.

But at the same time she is maintaining a more traditional Pasteur style, including assuring scientists of job security. She has also reaffirmed the institute's focus on basic research. Kourilsky was seen as shifting the institute's focus too much toward applied research, Ménard says. "That was a fundamental problem. Pasteur was starting to look like an enterprise," he says. "That was very shocking."

Money is likely to be the most limiting factor for all Dautry's plans. The state provides just a third of the private institute's $€ 205$ million budget, with another third coming from business income. For the rest the institute relies on philanthropy — and it's here that modernizing Pasteur's discreet fundraising activities can have the biggest impact, Dautry says. "We have to be more aggressive, and more aggressive abroad; it's not in France that we are going to find the money."

With an established network of infectious disease centers and training facilities in 30 developing countries, Pasteur could also benefit from the renewed emphasis on the field. Dautry is negotiating two large projects with the Bill \& Melinda Gates Foundation and other donors. "People need to know that we are not a French institute, but really international," she says.

In February, Dautry and the US Department of Health and Human Services launched a joint program in Asia to strengthen global surveillance for influenza, which includes building a biosafety level 3 lab in Phnom Penh, Cambodia. She is also in talks with US National Institutes of Health director Elias Zerhouni to create joint research programs and staff exchanges.

Closer to home, her personal approach is resulting in less use of email for internal communication. After the board resigned, Kourilsky famously emailed staff to announce that they would all receive a letter explaining his reforms and that he would "dialogue" with them in an Internet chat in which staff would have "perfect anonymity" so that "everyone can express themselves freely."

Dautry instead holds small meetings with staff where she discusses everything-including problems. "I'm using electronic memos less, I'm more for discussing with people directly," she says. "Voila! This way they know everything."

Declan Butler, Paris 